\title{
Data to the earthworm fauna of Myanmar with notes on some little known species (Annelida, Oligochaeta)
}

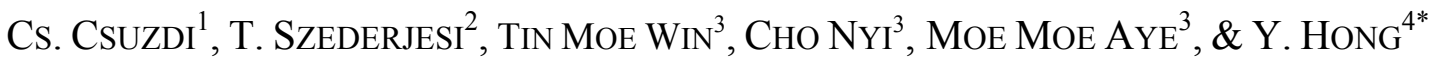 \\ ${ }^{1}$ Csaba Csuzdi, Department of Zoology, Eszterházy K. College, Eger, H-3300, Leányka u. 6. E-mail: \\ csuzdi.csaba@ektf.hu \\ ${ }^{2}$ Tímea Szederjesi, Department of Systematic Zoology and Ecology, Eötvös Loránd University, H-1117 Budapest, \\ Pázmány P. sétány 1/C.E-mail: t.szederjesi@gmail.com \\ ${ }^{3}$ Tin Moe Win, Cho Nyi \& Moe Moe Aye, Department of Zoology, University of Yangon, P. O. 11041, Yangon, Union \\ of Myanmar.E-mail: tinmoewin4@gmail.com \\ ${ }^{4}$ Yong Hong, Department of Agricultural Biology, College of Agriculture \& Life Sciences, Chonbuk National \\ University, Jeonju 561-756, Korea.E-mail: geoworm@hanmail.net*Corresponding author
}

\begin{abstract}
The earthworm fauna of the Republic of the Union of Myanmar (Burma) is quite well studied due to the studious works of Gordon E. Gates. However, after the publication of the comprehensive monograph Burmese earthworms (Gates 1972) there has been no new data published from this country. In the last year the last author collected several earthworm samples from Burma, resulting in 7 species records belonging to the families Moniligastridae, Benhamiidae, Octochaetidae and Megascolecidae including some little known species like Tonoscolex depressus (Gates, 1929) and Eutyphoeus constrictus Gates, 1929. Examination of the E. constrictus specimens revealed that they show different states of metandry, they are morphologically very similar to E. hastatus Gates, 1929, and only differ by the functionality of the testes in segment 10 , therefore it should be regarded as a synonym of E. constrictus.
\end{abstract}

Keywords. Burma, earthworms, Eutyphoeus, Tonoscolex, new synonym

\section{INTRODUCTION}

$\mathrm{T}$ he first data on the earthworm fauna of Myanmar (Burma) was presented by Rosa (1888, $1890 \mathrm{a}, 1890 \mathrm{~b})$ working on rich material collected by Leonardo Fea, a renowned Italian naturalist. In this series of papers Rosa reported 13 species new to science and Perionyx excavatus Perrier, 1872 being present in Myanmar. In the subsequent years several other sporadic datasets have been presented by Michaelsen $(1907,1908)$ and Stephenson $(1912,1916)$ and later, in the monograph of the Oligochaeta of British India, Stephenson (1923) listed 20 species occurring within the territory of the present day Myanmar.

In the middle of the 1920's the earthworm research of Burma got under way through the work of Gates, who organized a thorough collecting campaign and described some 80 species new to science (Gates 1972, Blakemore 2006). Unfortunately these activities ended abruptly because of WWII and Gates had to leave behind the collection and flee to the USA (Gates 1972). However, as a result of his 20 years of research, Gates continued publishing on the earthworms of Burma and finally produced a comprehensive monograph of the earthworm fauna of Burma reporting on 174 species occurring in Burma proper and another 84 species present in the neighbouring regions (Gates 1972). This list of earthworms has recently been updated by Blakemore (2006) reporting altogether 195 species of which ca. 130 are thought to be endemic to Myanmar.

After Gates' (1972) work, to the best of our knowledge, there have been no earthworm records 
presented from Myanmar, until the last author $(\mathrm{YH})$ organized several collecting trips to the country resulting in the description of the full mitochondrial genome of the giant Burmese earthworm Tonoscolex birmanicus (Gates, 1927) (Wang et al. 2015) and a report on some little known species presented herein.

\section{MATERIAL AND METHODS}

Earthworms were collected by the diluted formaldehyde method (Raw 1959), complemented with digging and searching under stones and under the bark of fallen logs. The specimens were killed and fixed in $96 \%$ ethanol, then transferred into $75 \%$ ethanol and deposited in the earthworm collection of the Hungarian Natural History Museum (HNHM). The penial setae were removed by dorsal dissecting of the animals, mounted in Euparal on a microscopic slide and were studied using a Nikon Eclipse 660 DIC microscope.

\section{RESULTS}

\section{Family Moniligastridae Claus 1880}

\section{Genus Drawida Michaelsen 1900}

\section{Drawida sp. juv.}

Material examined. HNHM AF/5637 7 ex. He Ywa Ywama, Taung Chaung Quarter, Inle lake $\left(20^{\circ} 29.26^{\prime} \mathrm{N}, 096^{\circ} 53.08^{\prime} \mathrm{E}\right), 920 \mathrm{~m}$. Naungshwe Township of Taunggyi district of Shan State, drain and beside of drain. 24. August 2014, leg. Y. Hong, Tin Moe Win \& Cho Nyi.

Remarks. We have several aclitellate specimens from this medium sized $(50 \times 3 \mathrm{~mm})$ species. Their colour is grey with slight greenish hints. They have no clitellum and any other genital markings. Male pores obvious, lateral in 10/11. Four intestinal gizzards in segment 13-16. Prostates long, finger-like, muscular. Ovisac long extends back to 17. Taking into account these characteristics our specimens are most similar to Drawida caerulea Gates, 1926 but they lack the characteristic blue colour.
Family Benhamiidae Michaelsen, 1897

Genus Dichogaster (Diplothecodrilus) Csuzdi,
1996

Dichogaster (Diplothecodrilus) annae (Horst, 1893)

Benhamia annae Horst, 1893: 32.

Dichogaster curgensis Michaelsen, 1921: Gates 1961: 57, Gates 1972: 280.

Dichogaster (Diplothecodrilus) annae: Blakemore 2006:15, Csuzdi 2010: 194 (for complete synonymy).

Material examined. HNHM AF/ 5639, 10 ex. Quarter 3 B, Bo Aung Kyaw Street, Hopong Town, Southern Shan State. $22 \mathrm{~km}$ distance from Taunggyi, found in soil nearby house. 22. August 2014, leg. Y. Hong, Tin Moe Win \& Cho Nyi.

Remarks. This species has previously been recorded from Burma under its synonymous name Dichogaster curgensis by Gates (1961).

\section{Dichogaster (Diplothecodrilus) saliens (Beddard, 1893)}

Microdrilus saliens Beddard, 1893683.

Dichogaster saliens: Gates 1942: 134, Gates 1972: 281.

Dichogaster (Diplothecodrilus) saliens: Blakemore 2006: 16, Csuzdi 2010: 116 (for complete synonymy).

Material examined. HNHM AF/ 5638, 2 ex. Quarter 3 B, Bo Aung Kyaw Street, Hopong Town, Southern Shan State. $22 \mathrm{~km}$ distance from Taunggyi, found in soil nearby house. 22. August 2014, leg. Y. Hong, Tin Moe Win \& Cho Nyi.

\section{Family Octochaetidae Michaelsen, 1900}

\section{Genus Eutyphoeus Michaelsen, 1900}

\section{Eutyphoeus constrictus Gates, 1929}

\section{(Figure 1)}

Eutyphoeus constrictus Gates, 1929: 28, Gates 1972: 290, Blakemore 2006: 16.

Eutyphoeus hastatus Gates, 1929: 32, Gates 1972: 295, Blakemore 2006: 16. syn. nov.

Eutyphoeus hamatus Gates, 1930: 332.

Eutyphoeus montanus Gates, 1933: 587. 


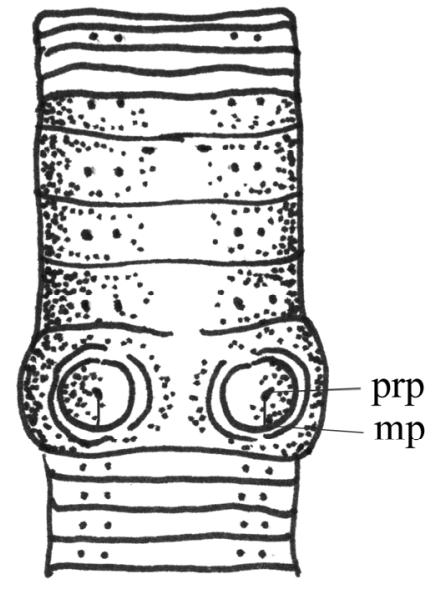

Figure 1. Eutyphoeus constrictus, ventral view of the clitellar region. $\mathrm{prp}=$ prostate pore, $\mathrm{mp}=$ male pore .

Material examined. HNHM AF/5642, 1 ex. Thar Si kone village. Laymyethna Township (17 $69.16^{\prime} \mathrm{N}, 95^{\circ} 06.49^{\prime} \mathrm{E}$ ), Laymyethna Township in the Hinthada District, Ayeyarwady Region, southwest Myanmar. $41.9 \mathrm{~km}$ from Hinthada, garden with leaf-litter, Yae phyu creek and garden. 15. August 2013, leg. Cho Nyi. HNHM AF/ 5643, 3 ex. Kala kone village, Aing Tha Pyu. (17 ${ }^{\circ} 53.13^{\prime}$ $\left.\mathrm{N}, 95^{\circ} 12.75^{\prime} \mathrm{E}\right)$. Cowdung pile. 13. August 2013, leg. Cho Nyi.

Diagnosis. Length 103-125 mm, diameter 4 $\mathrm{mm}$. Number of segments 180-216. Colour slightly red-violet on dorsum. Head schizolobous, first dorsal pore in 10/11. Clitellum circular on $1 / 2$ 13-17. Female pores anterior and slightly median to setae $a$ on 14. Prostatic pores on large circular porophores centered on 17. Male pores small on the posterior edge of the porophores near to $17 / 18$. Spermathecal pores large in $7 / 8$, in the setal line $c$.

Septa 5/6 thickened, 7/8 missing, 8/9 thin, 9/10-11/12 slightly thickened. Muscular gizzard large in 6. Dorsal vessel complete with last pair of hearts in 13. Calciferous glands large in 12. Typhlosolis from 28, lateral caeca small on 28. Ventral caeca numerous, 20-22 from segment 35. Supraintestinal glands large, 6-7 from around segment 60. Testes and funnels in 10 and 11. Those in 10 are small sometimes missing. Vesicles large in 12. Spermathecae in 7 bidiver- ticulate with short duct and larger oval ampoule. Prostates large, coiled in 17-20. Each prostate is accompanied with several penial setae. The mature setae slightly bent sabre-shaped, ca. 3-3.5 $\mathrm{mm}$ long $70 \mu$ at the widest region (just under the tip), $50 \mu$ at the middle. Ornamentation dense serrations.

Remarks. Our worms are clearly similar to $E$. hastatus Gates, 1929. The shape of spermathecae and the penial setae (Gates 1929 fig. 19) are completely identical with those of the present specimens, however hastatus is holandric, our specimens mainly metandric (with vestigial testis and male funnels in 10). But there are differences in the reduction of the first testes pairs, in one specimen it is much smaller but clearly functional, in the others hardly detectable, just the thin male duct can be seen. As the difference between $E$. constrictus and E. hastatus is quite small (absence or presence of functional testes in 10) Gates (1972) questioned the validity of this arbitrary distinction but formally kept the two species apart. As in our samples both forms appear, it is clear that E. hastatus Gates, 1929 is only a synonym name of $E$. constrictus Gates, 1929.

\section{Eutyphoeus foveatus Rosa, 1890}

\section{(Figure 2)}

Typhaeus foveatus Rosa, 1890a: 389.

Eutyphoeus foveatus: Gates 1972: 292, Blakemore 2006: 16.

Material examined. HNHM AF5641, 1 ex. Nyaung kone village, Aing Tha Pyu, Laymyethna Township in the Hinthada District, Ayeyarwady Region, south-west Myanmar. 41.9 km from Hinthada. $\left(17^{\circ} 53.68 ' \mathrm{~N}, 95^{\circ} 17.17^{\prime} \mathrm{E}\right)$, garden with leaf-litter. 12. August 2013, leg. Cho Nyi.

Diagnosis. Length $180 \mathrm{~mm}$ diameter $5 \mathrm{~mm}$. Color dark brownish-red on dorsum. Head epilobous, first dorsal pore in 11/12. Clitellum circular on $1 / 2$ $13-1 / 218$. Female pore anterior to setae $a$ left on 14. Prostatic pores in a large oval depression centered on 17. Male pores small, behind the prostatic pores. Spermathecal pores large in $7 / 8$, in the setal line $a b$. 


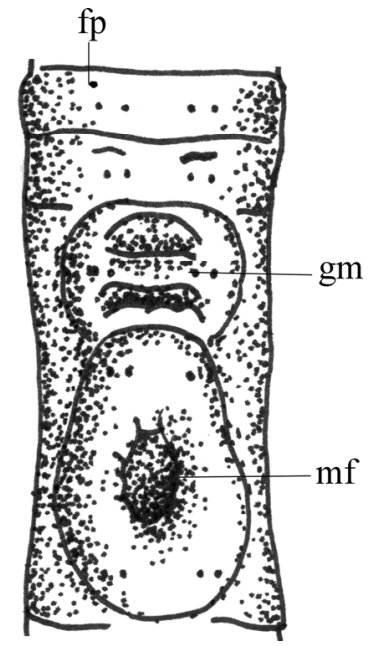

Figure 2. Eutyphoeus foveatus, ventral view of the clitellar region. $\mathrm{fp}=$ female pore $\mathrm{mf}=$ male field, $\mathrm{gm}=$ genital marking.

Muscular gizzard large in 8. Dorsal blood vessel aborted in front of segment 7. Calciferous glands large in 12. Metandric, testes and funnels 11. Vesicles large in 12. Spermathecae in 8 bidiverticulate with short duct and larger irregular ampoule. Prostates large, coiled, each prostate is accompanied with several penial setae. The mature setae slightly S-shaped, ca. $4.5 \mathrm{~mm}$ long and $25 \mu$ wide. Ornamentation dense spines.

\section{Genus Octochaetona Gates, 1962}

\section{Octochaetona surensis (Michaelsen, 1910)}

Octochaetus surensis Michaelsen, 1910: 88.

Octochaetus (Octochaetoides) birmanicus Gates, 1925: 55.

Octochaetona surensis: Gates 1962: 213, Gates 1972: 309, Blakemore 2006: 17.

Material examined. HNHM AF/5635, 5 ex., 5636, 4 ex. South of Yangon, near Thilawa port, Kyauktan. Seikkan Township, Yangon Region. $\left(16^{\circ} 46.20^{\prime} \mathrm{N}, 96^{\circ} 15.47^{\prime} \mathrm{E}\right)$. 26. August 2012, leg. Y. Hong \& Tin Moe Win.

\section{Family Megascolecidae Rosa, 1891}

Genus Tonoscolex Gates, 1933

Tonoscolex depressus (Gates, 1929)

Notoscolex depressus Gates, 1929: 14.
Notoscolex choprai Stephenson, 1929: 230.

Tonoscolex depressus: Gates 1933: 484, Gates 1972: 228, Blakemore 2006: 11.

Material examined. HNHM AF/5640, $3+2$ juv ex. Loi San Sit mountain, Lashio. Northern Shan State. $\left(23^{\circ} 25.30^{\prime} \mathrm{N}, 097^{\circ} 05.80^{\prime} \mathrm{E}\right) 1441 \mathrm{~m}$. 15. August 2013, leg. Y. Hong \& Tin Moe Win.

Diagnosis. Length $75-80 \mathrm{~mm}$, diameter 3-4 $\mathrm{mm}$. Colour yellowish. Setae lumbricine, head epilobous, first dorsal pore in 11/12. Clitellum not completely developed, circular on 12-16. Female pore between setae $a a$, right on 13. Combined male and prostatic pores open in V-shaped seminal groves in 17. Spermathecal pores two pairs in $6 / 7 / 8$.

Muscular gizzard large in 6. Dorsal blood vessel complete, last hearts in 12. Calciferous glands paired, with small stalks and join the oesophagus in 9-12. Holandric, testes and funnels in 9-10. Vesicles in 10-11. Spermathecae in 6-7 unidiverticulate with short duct and larger irregular ampoule.

Remarks. The genus is characterized by the special enteroic excretory system and the seemingly unusual positions of the genital organs (female pores in13, prostatic pores in 17 testes in 9, 10). However, dissecting the buccal cavity revealed a retracted vestigial first segment (Fig. 3 ). Adding this to the segment count would mean all the strange positions would shift to the normal place (ie. testes 10,11 , female pores 14 , prostatic pores 18 ).

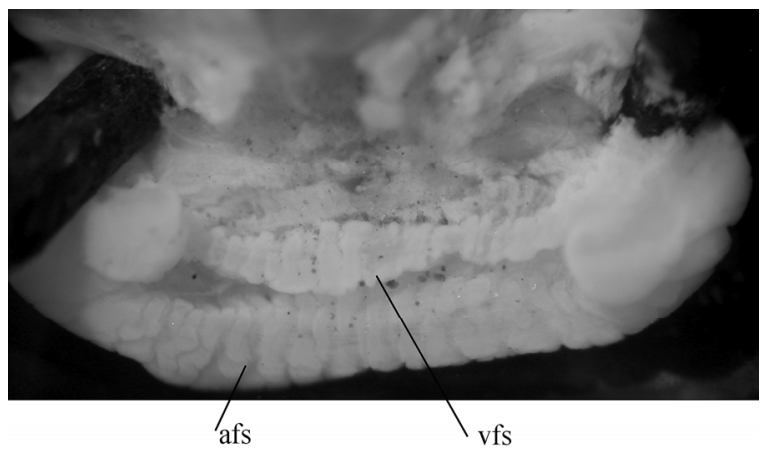

Figure 3. Tonoscolex depressus, buccal cavity. afs = apparent first segment, vfs = vestigial first segment retracted into the buccal cavity. 
Our present specimens completely agree with the description of Gates $(1929,1972)$ and are well recognizable by the characteristic male field (Gates 1929, Fig. 6). However, all the three mature worms are at the lower range of the species' size variation $(75-500 \mathrm{~mm}$ by Gates 1972).

Acknowledgments - This research was supported by Korea Rural Development Administration fund (PJ009778). Our thanks are due to Emma Sherlock (NHM, London) for polishing the English of the Ms. Comments and suggestions of the anonymous reviewers are also kindly acknowledged.

\section{REFERENCES}

BEDDARD, F.E (1893): On some new species of earthworms from various parts of the world. Proceedings of the Zoological Society of London, 1893: 666-706. doi: 10.1111/j.1096-3642.1892.tb01789.x

BlaKemORE, R.J. (2006): Checklist of Myanmar taxa updated from Gates' (1972): "Burmese Earthworms". In. KANEKO N. \& ITO, M.T. (Eds.) A Series of Searchable Texts on Earthworm Biodiversity, Ecology and Systematics from Various Regions of the World. $2^{\text {nd }}$ edition, Yokohama, p. 1-21.

CSUZDI, Cs. (2010): A monograph of the Paleotropical Benhamiinae earthworms (Annelida: Oligochaeta, Acanthodrilidae). In. CsUZDI, Cs \& MAHUNKA S. (Eds.) Pedozoologica Hungarica 6, Hungarian Natural History Museum, Budapest. 348 pp.

GATES, G.E. (1925): On some new earthworms from Rangoon, Burma II. Annals and magazine of natural history, 9(16): 49-64. doi: $\underline{10.1080 / 00222932508633274}$

GAteS, G.E. (1929): A Summary of the Earthworm Fauna of Burma with Descriptions of Fourteen New Species. Proceedings of the United States National Museum, 75(10): 1-41. doi: $\underline{10.5479 / \text { si.00963801.75-2781.1 }}$

GATES, G.E. (1930): The earthworms of Burma I. Records of the Indian Museum, 32: 257-356.

GATES, G.E. (1933): The Earthworms of Burma. IV. Records of the Indian Museum, 35: 413-606.

Gates, G.E. (1942): Notes on Various Peregrine Earthworms. Bulletin of the Museum of Comparative Zoology at Harvard College, 89: 63-144.
GAtES, G.E. (1961): Earthworms of Burma. Burma Research Society Fiftieth Anniversary Publications, 1: 51-58.

GATES, G.E. (1962): Contributions to a revision of the earthworm family Octochaetidae. I-II. Annals and magazine of natural history, 13(5): 209-215. doi: $10.1080 / 00222936208651237$

GATES, G.E. (1972): Burmese Earthworms, an introduction to the systematics and biology of Megadrile oligochaetes with special reference to South-East Asia. Transactions of the American Philosophical Society, 62(7): 1-326.

HoRsT, R. (1893): Earthworms from the Malay Archipelago. Zoologische Ergebnisse einer reise in Niederländisch Ost-Indien, 3: 28-77.

MiCHAELSEN, W. (1907): Neue Oligochaten von Vorderindien, Ceylon, Birma und den Andaman-Inseln. Mitteilungen aus dem Naturhistorischen Museum in Hamburg, 24: 143-188.

MichaElSEN, W. (1908): The Oligochaeta of India, Nepal, Ceylon, Burma and the Andaman Islands." Memoirs of the Indian Museum, 1: 103-253.

MiCHAELSEN, W. (1921): Oligochäten vom westlichen Vorderindien und ihre Beziehungen zur Oligochätenfauna von Madagaskar und den Seychellen. Mitteilungen aus dem Naturhistorischen Museum in Hamburg, 38: 27-68.

MiChAELSEN, W. (1910): Die Oligochätenfauna der vorderindisch-ceylonischen Region. Abhandlungen des Naturwissenschaftlichen Vereins in Hamburg, 19(5):88.

RAW, F. (1959): Estimating earthworm populations by using formalin. Nature, 184: 1661-1662. doi: $\underline{10.1038 / 1841661 \mathrm{a} 0}$

RosA, D. (1888): Lombrichi della Birmania, del Tenasserim e dello Scioa. Bollettino dei Musei di Zoologia ed Anatomia comparata di Torino, 3(50): $1-2$.

RosA, D. (1890a): "Viaggio di Leonardo Fea in Birmania e Regioni vicini. XXV. Moniligastridi, Geoscolecidi ed Eudrilidi." Annali del Museo Civico di Storia Naturale di Genova, 9: 386-400.

RosA, D. (1890b): "Viaggio di Leonardo Fea in Birmania e Regioni vicini. Perichetidi." Bollettino dei Musei di Zoologia ed Anatomia comparata di Torino 30: 107-122. 
STEPHENSON, J. (1912): Contributions to the fauna of Yunnan. VIII. Earthworms." Records of the Indian Museum, 7: 273-278.

STEPHENSON, J. (1916): On a Collection of Oligochaeta Belonging to the Indian Museum." Records of the Indian Museum, 12: 294-354.

Stephenson, J. (1923): Oligochaeta. The Fauna of
British India including Ceylon and Burma. Taylor and Francis, London. pp. 518.

WANG, A.R., Hong, Y., TIN MoE WIN \& KIM, I.S. (2015): Complete mitochondrial genome of the Burmese giant earthworm, Tonoscolex birmanicus (Clitellata: Megascolecidae). Mitochondrial DNA, 26(3): 467-468.

doi: $\underline{10.3109 / 19401736.2013 .830300}$ 